UNIVERSITY OF WASHINGTON

DEPARTMENT OF OCEANOGRAFHY

Seattle, Washington 98105

Technical Reports

Nos. $276,277,278$ and 279

A COMPIIATION OF ARTICIES REPORTING RESEARCH

SPOIISORED BY

TIE OFFICE OF NAVAI RESEARCH

Office of Naval Research

Contract Nonr-477(37)

Reference $M 72-4 I$

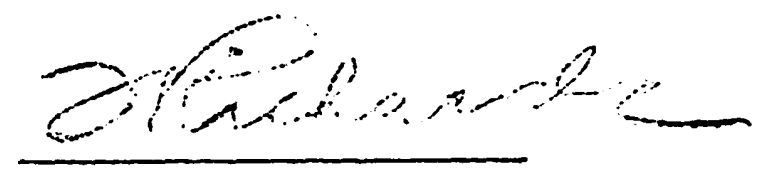

FRANCIS A. RICHARDS

Principal Investigator

Reproduction in part or in whole is premitted

for any purpose of the United States Government 
ARTICLES REPORTIIVG RESEARCH SPONSCRED BY THE OFFICE OF NAVAL RESEARCH

Technical Report No. 276

IATE QUTATERITARY TECTONICS, IIORTHERN END OF JUAN DE FUCA RIDGE (NORTHEAST FACIFIC), by Dean A. MCManus, Mark I. Holmes, Bobb Carson and Sandra Mi. Barr. Marine Geology, 12: 141-164. 1972

Technical Report No. 277

A GYROCCMPASS FOR MEASUREMENT OF CORE ORIENTATICN AND CORE BEEAVICR, by Douglas R. Morrison and Bobb Carson. Dcep-Sea Research, 18: 935-939. 1971.

Technical Report No. 278

VOLTAMMETRIC MEASURIMENT OF ZINC IN THE NCRTHEASTERN TROPICAL PACIFIC OCEAN, by A?berto Zirino and Michesl L. Healy. Limnology and Oceanography, 16(5): 773-778. 1971.

Technical Report No. 279

FH-CONIROIJED DIFFERENTIAI VOITAMMETRY OF CERTAIN TRACE TRANSITION ELEMENTS IN NATURAL WATERS, by Alberto Zirino and Michael I. Healy. Envirormental Science \& Technology, 6(3): 243-249. 1972. 


\section{LATE QUATERNARY TECTONICS, NORTHERN END OF JUAN DE FUCA RIDGE (NORTHEAST PACIFIC)}

DEAN A. MCMANUS ${ }^{1}$, MARK L. HOLMES ${ }^{1}$, BOBB CARSON1 ${ }^{1}$ AND SANDRA M. BARR ${ }^{2}$

1 Department of Oceanography, University of Washington, Seattle, Wash. (U.S.A.)

2 Department of Geology, University of British Columbia, Vancouver, B.C. (Canada)

(Received July 17, 1971)

\section{ABSTRACT}

McManus, D. A., Holmes, M. L., Carson, B. and Barr, S. M., 1972. Late Quaternary tectonics, northern end of Juan de Fuca Ridge (northeast Pacific). Mar. Geol., 12: 141-164.

Seismic reflection profiles from the northern end of Juan de Fuca Ridge reveal three axial valleys having a basement relief of as much as $2 \mathrm{sec}$ (two-way travel time). A thick sequence, presumably of turbidites, mainly less than 0.7 m.y. old, covers much of the area. The oldest turbidites form the upper part of the fill of a possible Tertiary trench between the ridge and North America. The second turbidite unit extends beyond the trench and once formed an abyssal plain over most of northern Juan de Fuca Ridge and the area west to Explorer Ridge. Following formation of the plain, vertical movements began that broadly uplifted the crest of Juan de Fuca Ridge, block-faulted its northern end, produced faulting along Sovanco Fracture Zone, and upwarped the basement north of the ridge. Younger turbidites have filled the lowlands created by the vertical movements. The present sea floor topography and seismic activity show evidence of continued movements.

Our findings indicate that the basement relief of the ridge crest and fracture zone were formed after the time of creation of the magnetic anomalies associated with sea floor spreading. Although abruptly initiated, these vertical movements have continued in a moderated form to the present. The vertical movements are thought to be associated with horizontal plate motions in this complex area and with the episodic release of strain as the northwest-salient block of the Juan de Fuca Plate is possibly being severed from the remainder of the plate.

\section{INTRODUCTION}

This study is concerned with block faulting, tilting, and warping at the crest of a part of the mid-ocean ridge system. Such movements may be the surface expression of the large-scale uplift which has been ascribed to thermal expansion associated with the implacement of new lithosphere along the crest (LANGSETH et al., 1966; MCKENZIE and SCLATER, 1969). Because most ridge crests are either devoid of sediment or are covered by only a veneer of topography-conforming pelagic deposits, it is normally difficult to determine the history of crestal tectonics, as offset depositional units cannot be located. However, terrigenous turbidites occur in the vicinity of the axis of Juan de Fuca Ridge. By assuming that continuity with the continental sediment source must have existed while these terrigenous 
turbidites were being deposited, and by assuming that the course of the bottomseeking currents that deposited the turbidites must have been directed by the topographic relief and bottom gradient, which are two sensitive indices of relative vertical tectonic movement, then inferences on the sequence of tectonic events evidenced in the sediments are possible. Vertical movements between times of turbidite accumulation can produce different sediment distributional patterns. Tilting movement can be noted by the rotated position of the originally horizontal or nearly horizontal layers of the turbidite sequence. ATWATER and MUDIE (1968) made use of this principle in inferring the history of vertical movement in the medial valley of Gorda Ridge, and HAMILTON and MENARD (1968) noted movements of Juan de Fuca Ridge from such data. If part of the axis of a ridge, therefore, has been buried by turbidites, a study of seismic profiles from the area might add considerable information about the vertical movements at a ridge crest.

The crestal topography of Juan de Fuca Ridge is characterized by low relief and a poorly-defined medial valley (MCMANUs, 1967; MENARD and MAMMERICKX, 1967). The relief of the medial valley near the southern end of the ridge is only 60 fathoms (110 m) (Melson, 1969), and at the northern end it is 300 fathoms $(550 \mathrm{~m})$ (McManus, 1967). Nevertheless, a seismic reflection profile across the northern end of the ridge revealed a buried axial valley filled with 1 second of sediment (Ewing et al., 1968). Because the northern end of Juan de Fuca Ridge appeared to have a turbidite-filled axial valley, a brief seismic reflection survey was made in October 1970 of this area and the junction with the Sovanco Fracture Zone (Fig.1) to obtain information on the vertical movements at the crest of the ridge. Preliminary results of the tectonics of part of the area have been reported by CHASE et al. (1970).

\section{REGIONAL SETTING}

\section{Topography}

Juan de Fuca Ridge is partly covered from the east by the deep-sea fan deposits flooding Cascadia Basin (Fig.1). At the northern end of the ridge crest only a few, small, individual ridges extend above the generally smooth surface of the sea floor (Fig.2). East, Middle and West ridges have a relief of 60-300 fathoms (110-550 m) and each ridge, in turn, appears to be composed of short, individual segments. The trend of these three ridges, representing the crest of Juan de Fuca Ridge, is intersected by that of Sovanco Ridge, the topographic expression of the Sovanco Fracture Zone (PAvoni, 1966). The relief of Sovanco Ridge is as much as 600 fathoms $(1,100 \mathrm{~m})$ on the south side. To the northwest, crossing the northwest corner of Fig.2, is Explorer Ridge, the continuation of the mid-ocean ridge system. At the north edge of the figure, the northwest-trending ridges bordering Vancouver Gap are part of the Scott Islands Fracture Zone (CоucH, 1969) which parallels the adjacent continental slope off Vancouver Island. 


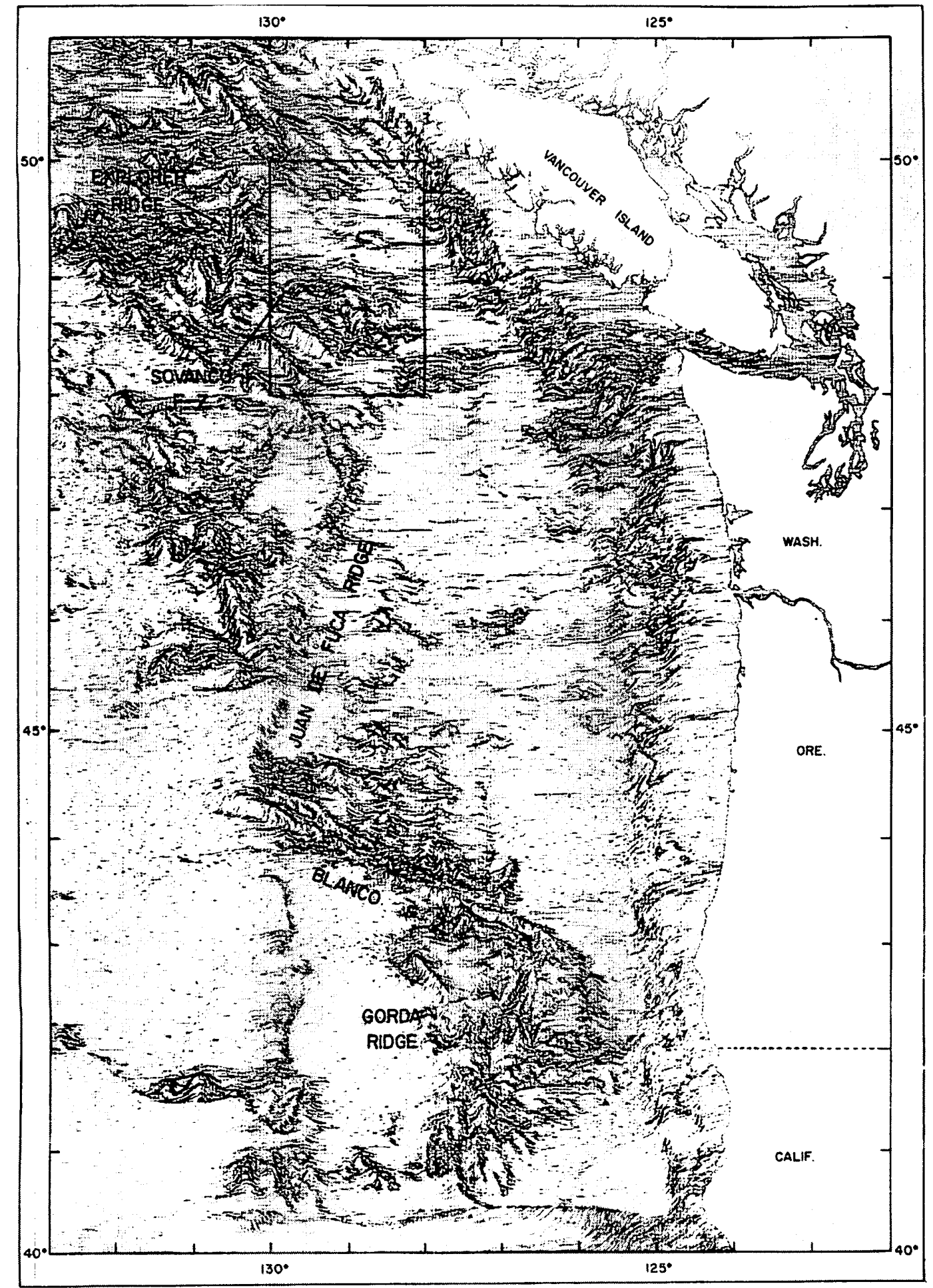

Fig.1. Physiographic diagram of part of Northeast Pacific showing location of study area. Cascadia Basin lies between Juan de Fuca Ridge and the continental margin. Scott Islands Fracture Zone is at the northern end of Explorer Ridge. Diagram prepared by Noel McGary. 


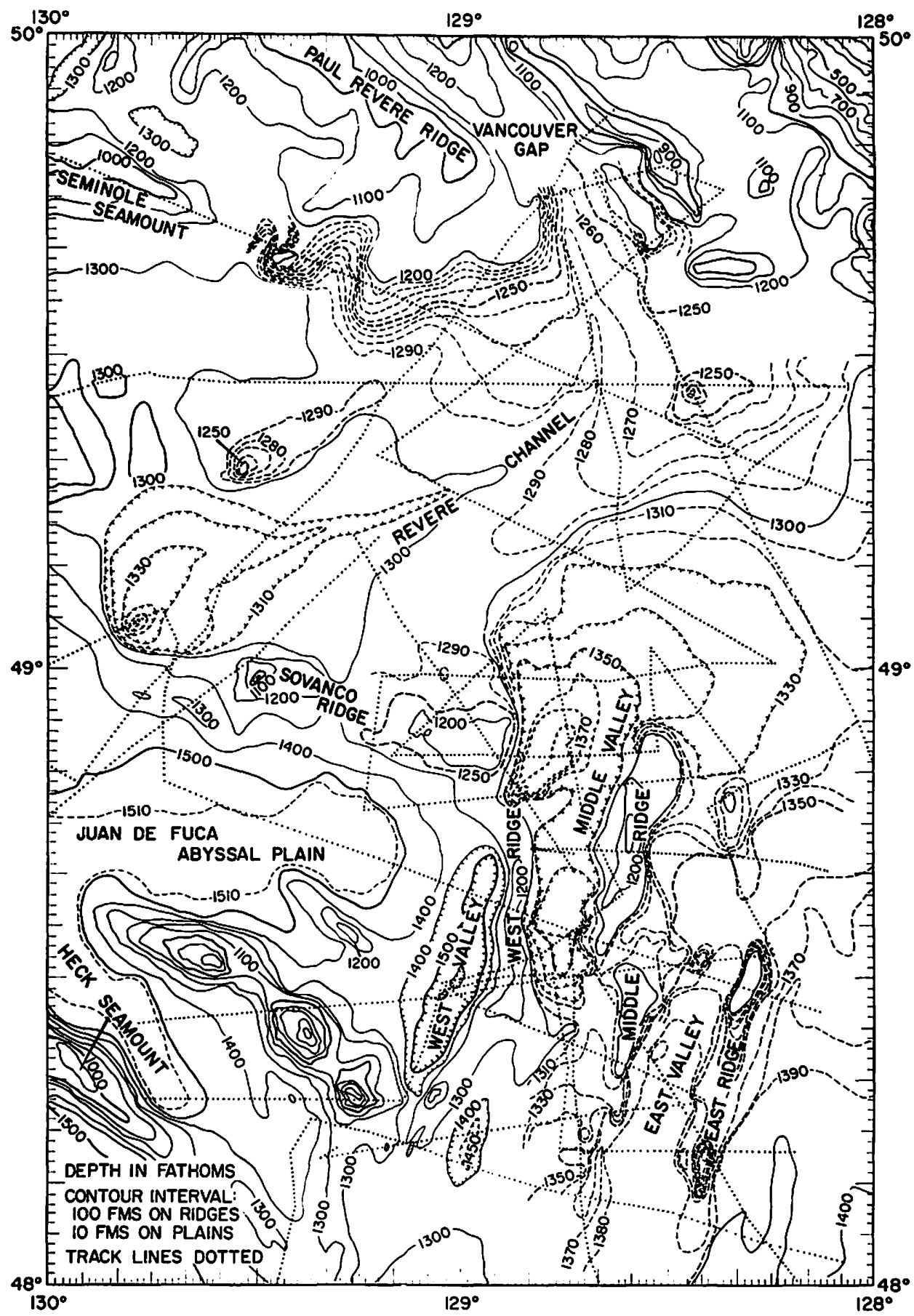

Fig.2. Bathymetric chart, based upon track lines shown, plus available soundings from survey by U.S.C. and G.S. ship "Pioneer". Contours at northern edge of chart are from HURLEY (1960). 
Between many of the ridges the sea floor is relatively smooth. Nevertheless, the low-relief areas display a complex topography. From Vancouver Gap on the north, the sea floor slopes regionally southward. However, Revere Channel apparently does not cross Cascadia Basin to the southeast. Instead, it turns to the southwest and ends against Sovanco Ridge. An abandoned channel may pass through the ridge a short distance west of the study area and join Juan de Fuca Abyssal Plain, south of the ridge. Small, natural levees border Revere Channel. Although most of the sea floor formed by the channel and levee system is smooth, in certain areas it is hummocky: at the southern end of Paul Revere Ridge, along the northern margin of Sovanco Ridge, and along the southeastern margin of the levee system, where the gradient is steeper.

Southeast of the levee system, the sea floor is smoother but it is segmented by the crestal ridges of Juan de Fuca Ridge into relatively isolated basins. Middle Valley is one such basin, containing two sub-basins. Along the east, west and south sides of Middle Valley the smooth floor passes into a hummocky or step topography rising slightly toward the adjacent ridge. In the northern sub-basin, the topography steps downward from the east and west toward the middle of the sub-basin. In East Valley the floor is relatively smooth, sloping slightly to the south, but on the east side of East Ridge, hummocky topography again marks a margin against a ridge. These topographic disturbances indicate the possibility of recent vertical tectonic movements.

\section{Magnetic anomalies}

The magnetic anomaly chart of RAFF and MASON (1961) includes the study area (Fig.3). Two major trends in the anomaly patterns are evident: the northeast trends associated with Juan de Fuca Ridge in the south and Explorer Ridge in the north, and the northwest trend of the Sovanco Fracture Zone. A confused pattern, or lack of pattern, characterizes the northeast part of the study area.

On the east side of Juan de Fuca Ridge anomaly number 2, representing an age of 1.78-1.93 m.y. (HeIRTZLER et al., 1968), is located just east of East Ridge. On the west side of Juan de Fuca Ridge anomaly number 2 passes through the two small seamount ranges. For the axial anomaly, with an age $<0.7 \mathrm{~m}$.y., the eastern edge is at the eastern edge of Middle Ridge and the western edge approximates the terminus of the two small seamount ranges. The negative sign of part of the axial anomaly appears to result from the choice of the reference field.

\section{Earthquake epicenters}

Epicenters for earthquakes occurring during the period 1954-1963 (ToBIN and SYKES, 1968) are restricted to the northern half of the area (Fig.3). The virtual lack of recorded seismic activity on Juan de Fuca Ridge has often been noted (e.g., ToBIN and SyKES, 1968). The accuracy of the epicentral locations is estimated by TOBIN and SYKes (1968) to be less than a few tens of kilometers. Some of the 


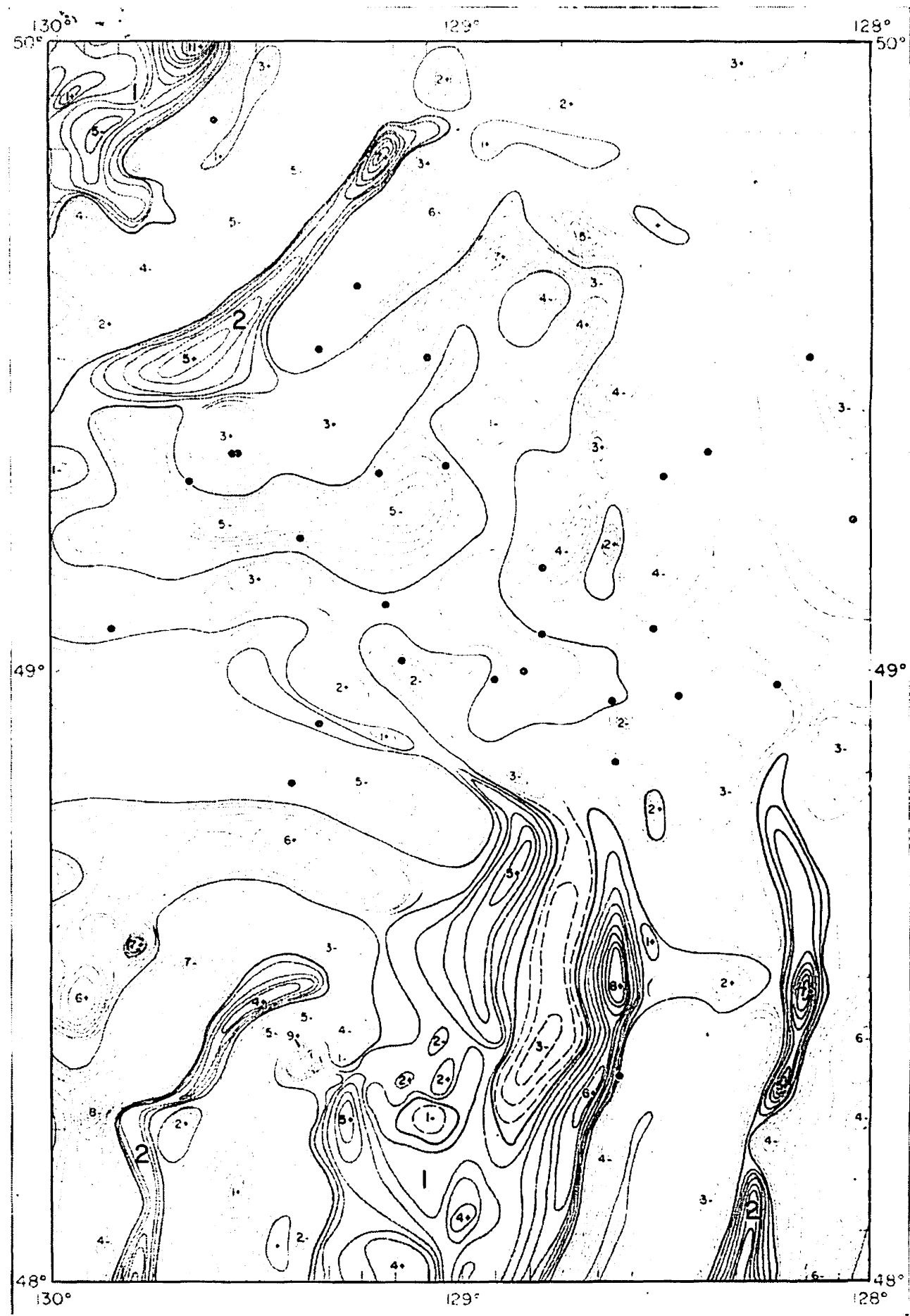

Fig.3. Chart of magnetic anomalies of the total magnetic field (from RAFF and MASON, $1961)$ and earthquake epicenters (TOBIN and SYKES, 1968). Magnetic anomaly contour interval is 100 gammas; positive anomalies are shown by solid lines, negative anomalies by dashed lines. Large numerals and shading identity anomalies $l$ and 2 according to the system of HeIRTZLer et al. (1968). Dots represent earthquake epicenters. 
epicenters, therefore, are apparently associated with the Sovanco Fracture Zone. Much of the activity, however, cannot be ascribed to any particular tectonic feature. Rather, it is assignable only to the block between the northern end of Juan de Fuca Ridge and Vancouver Island.

\section{ASSUMED STRATIGRAPHIC UNITS FROM SEISMIC PROFILES}

Seismic reflection profiles were obtained along 480 nautical miles $(890 \mathrm{~km})$ of track during cruise TT-53 (R.V. "Thomas G. Thompson") using a 40 cubic-inch airgun at approximately 2,000 p.s.i. and a 5 -sec firing rate. Recording of the $40-80$ $\mathrm{Hz}$ band was made on a modified EDO PBR-333 recorder at a 5-sec scale. The ship speed was approximately 8.5 knots throughout most of the survey and positioning was based on satellite fixes. Two legs of the survey (TT-48) (180 nautical miles or $333 \mathrm{~km}$ ) were made without satellite navigation and with slightly different recording equipment and hydrophones.

In interpreting the profiles, the depth below the sea floor to a reflector and the thickness of sedimentary units are presented in two-way travel time, rather than distance (meters), because of uncertainty as to sonic velocity in the sediments. A velocity of $2 \mathrm{~km} / \mathrm{sec}$ is often assumed for sediments, and in seismic refraction studies in the southern extremity of Cascadia Basin (Gorda Basin) velocities of $2.00-2.20 \mathrm{~km} / \mathrm{sec}$ were measured with a value of $2.09 \mathrm{~km} / \mathrm{sec}$ being used in the computation (SHOR et al., 1968). However, a short distance away, in the medial valley of Gorda Ridge, down-hole acoustic logging at Site 35 of the JOIDES Deep Sea Drilling Project measured velocities in much the same, if not identical, sediment sequence (Pleistocene turbidites) that ranged from less than $1.4 \mathrm{~km} / \mathrm{sec}$ to more than $2.5 \mathrm{~km} / \mathrm{sec}$, depending upon the lithology and related properties (McMANus, 1970). In the older, predominantly Tertiary, sediments of outer Delgada Fan off northern California, laboratory sonic velocity measurements of JOIDES cores showed velocities averaging $1.4 \mathrm{~km} / \mathrm{sec}$ in the younger sediments and $1.9 \mathrm{~km} / \mathrm{sec}$ in sediments near the basalt. The average for the complete section was $1.5 \mathrm{~km} / \mathrm{sec}$ (MCMANus, 1970). At both of these sites the average velocity is different in different parts of the section and the same result might be expected in the turbidite sequence of the present study area. Therefore, because all of the feasible values for the sonic velocity in sediments appear likely, no basis is present for selecting one over another. Accordingly, the data are presented in two-way travel time.

\section{Acoustic basement}

Acoustic basement, presumably basalt, is easily discernible on the seismic profiles with the exception of areas where it lies more than approximately $2 \mathrm{sec}$ beneath the sea floor (Fig.4). These areas occur in the northeast corner of the study area, nearest the continental margin, and beneath Middle Valley.

The ridge and valley surface topography on Juan de Fuca Ridge is repeated 


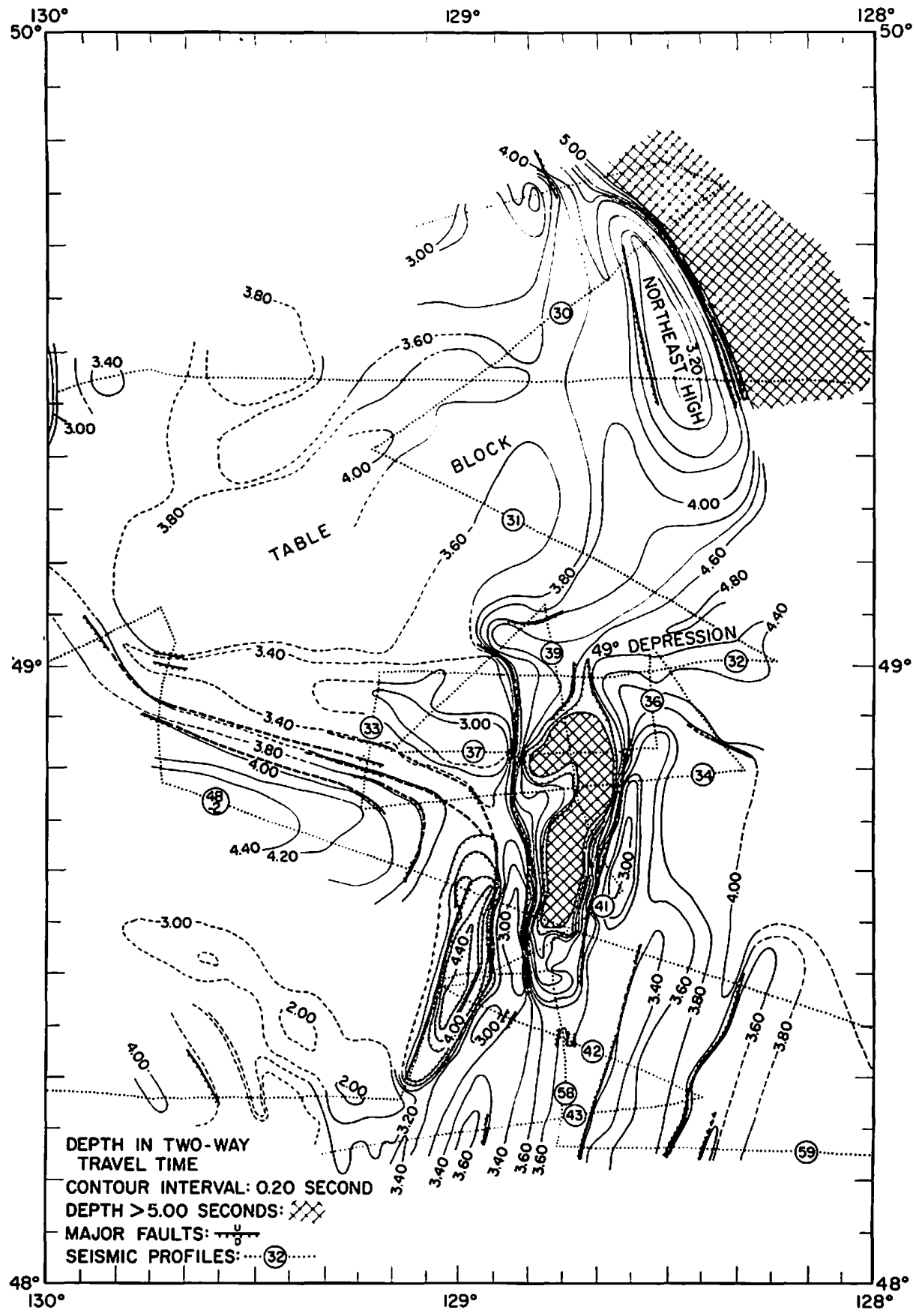

Fig.4. Topographic chart of acoustic basement. Numerous small faults are omitted. Seismic profiles identified arc illustrated in Fig.5-10. 
with greater relief in the topography of the acoustic basement, which has as much as 2-sec relief. The progressive northward loss of bottom surface relief of East, West, and Middle ridges is repeated in the basement topography. At the northern end of Middle Valley, at about $49^{\circ} \mathrm{N}$, the basement rises slightly into a shallower depression oriented roughly east-west, the $49^{\circ}$ Depression. To the east, this depression passes into the basement low, bordering the continent, that apparently is a filled Tertiary trench along western North America (ATwATER, 1970). The $49^{\circ}$ Depression (Fig.4) may also extend westward along the north side of Sovanco Ridge.

To the north, a small basement high at the southern end of Paul Revere Ridge and the Northeast basement high have more of a north-south trend than do the main ridges of the Scott Islands Fracture Zone. These small highs almost seem to form part of an arcuate pattern connecting the northwest trend of the fracture zone with the northeast trend of Juan de Fuca Ridge. East of Northeast High the ridges in the sea floor topography are formed by sediments in the complicated structures associated with the adjacent continental margin (Fig.5, Leg 30). These are not discussed in this study. South of Northeast High the basement drops from Table Block into the $49^{\circ}$ Depression (Fig.5, Leg 31). This change in basement slope is also reflected in the gentle change in slope of the sea floor at the southeastern margin of the levee of Revere Channel.

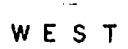

E A S T

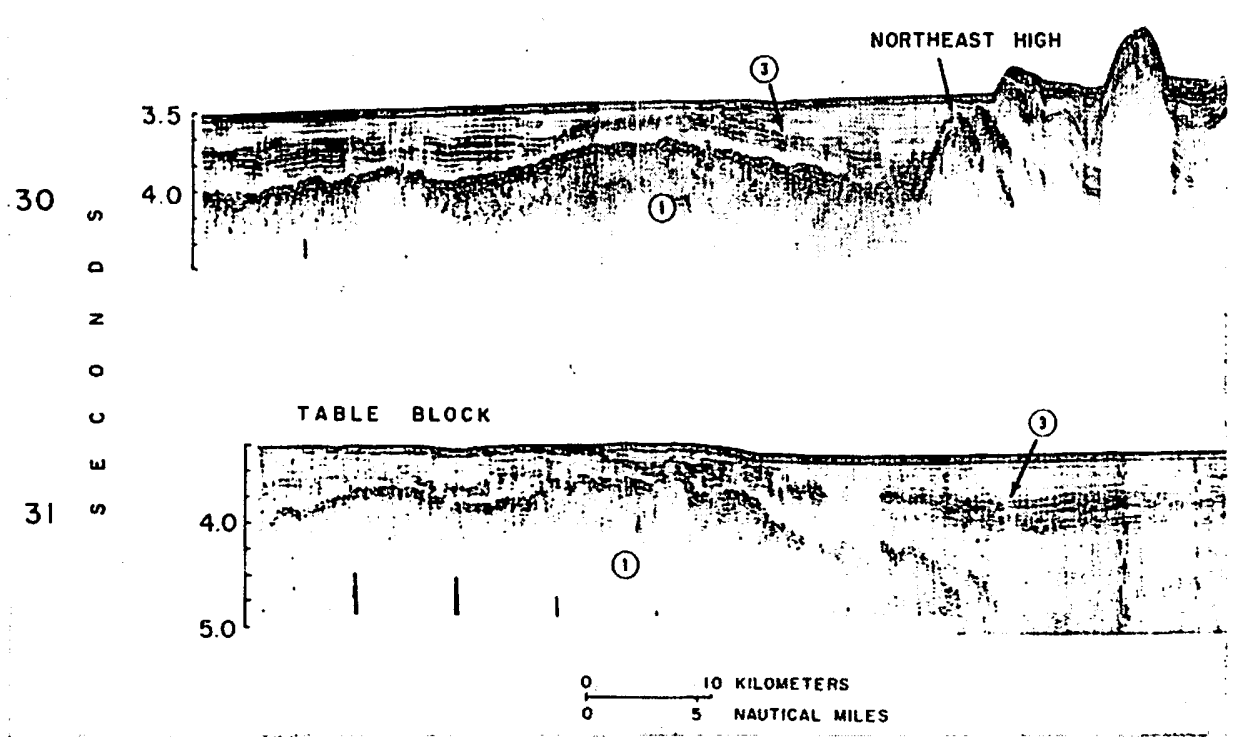

Fig.5. Seismic reflection profiles TT-53, Legs 30 and 31. Vertical exaggeration: $\times 10.5$. In profile 31 the Lower Turbidites consist of unit $A$ (transparent) in the lower part and unit $B$ (strong reflectors) above. In profile 30 unit $B$ rests on the acoustic basement. $l=$ acoustic basement; $2=$ Lower Turbidites; $3=$ Lower/Upper Turbidite contact; $4=$ Upper Turbidites. 
The basis in the seismic profiles for the existence of major basement faults will be presented in the next two sections. Although some of the major basement faults occur in the northern part of the study area, the main faulting is on Juan de Fuca Ridge and the Sovanco Fracture Zone (Fig.4). The thick sediment fill between the fault-controlled walls of Middle Valley is shown in Fig.6 and Fig.7 (Leg 41). West Valley is a similar structure (Fig.7, Legs 41 and 42) but contains less sediment. Some of the faults along West Ridge appear to merge into those of Sovanco Ridge.

The abrupt southern termination of Middle and West Valleys is evident in the comparison of Legs 41 and 42 (Fig.7) for Middle Valley and Legs 42 and 43 (Fig.8) for West Valley. For Middle Valley the basement rises from a depth of $4.95 \mathrm{sec}$ to $3.70 \mathrm{sec}$ in a distance of 10 miles $(18 \mathrm{~km})$ and the overlying sediment thins correspondingly. The basement appears to be warped (Fig.9, Leg 58), rather than faulted. Two aspects of the basement reflector on Leg 58 should be noted. First, side echoes produce reflectors that can be confused with the basement, as can be demonstrated from the crossing with Leg 42; and second, the basement is a smooth reflector. A smooth basement reflector is also noted in the southern extension of Middle and East Valleys on Leg 42 (Fig.7), in the extension of all three valleys on Leg 43 (Fig.8), and to both sides of East Ridge (Fig. 10). It may represent flat valley floors formed by basalt flows. Locally, the sea floor in the medial valley

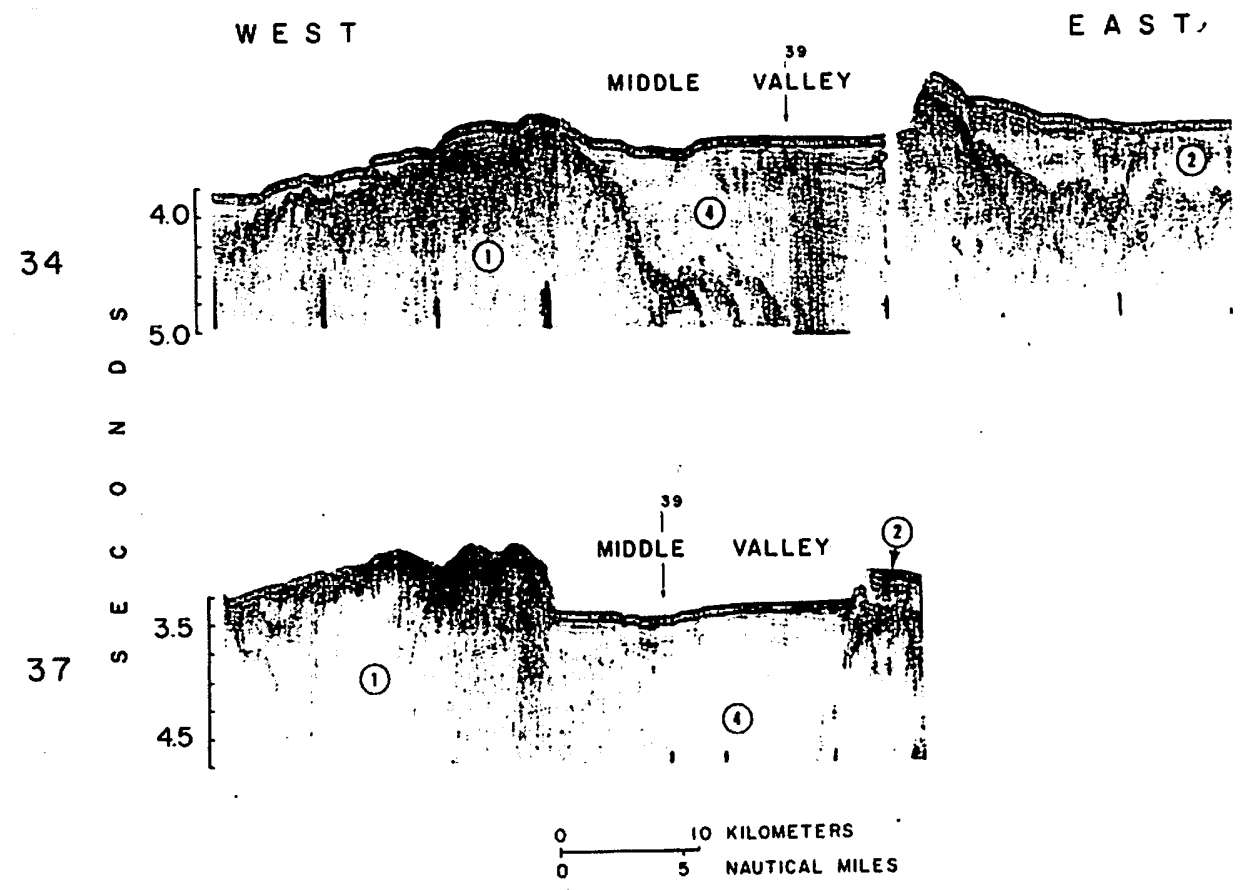

Fig.6. Seismic reflection profiles TT-53, Legs 34 and 37. Vertical exaggeration: $\times 10.5$. Small arrows indicate crossing points of other legs. For key to numbers, $1-4$ see legend of Fig.5. 


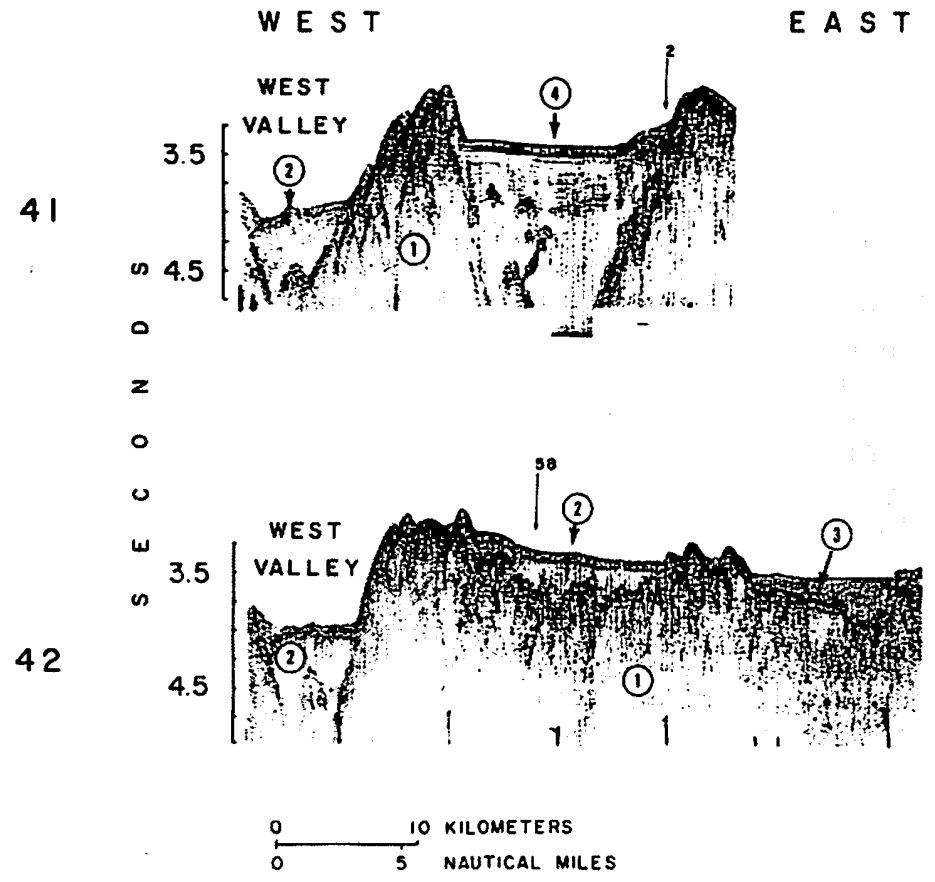

Fig.7. Seismic reflection profiles TT-53, Legs 41 and 42 . Vertical exaggeration: $\times 10.5$. Small arrows indicate crossing points of other legs. Leg 58 is along the southern extension of Middle Valley. For key to numbers $1-4$, see legend of Fig.5.

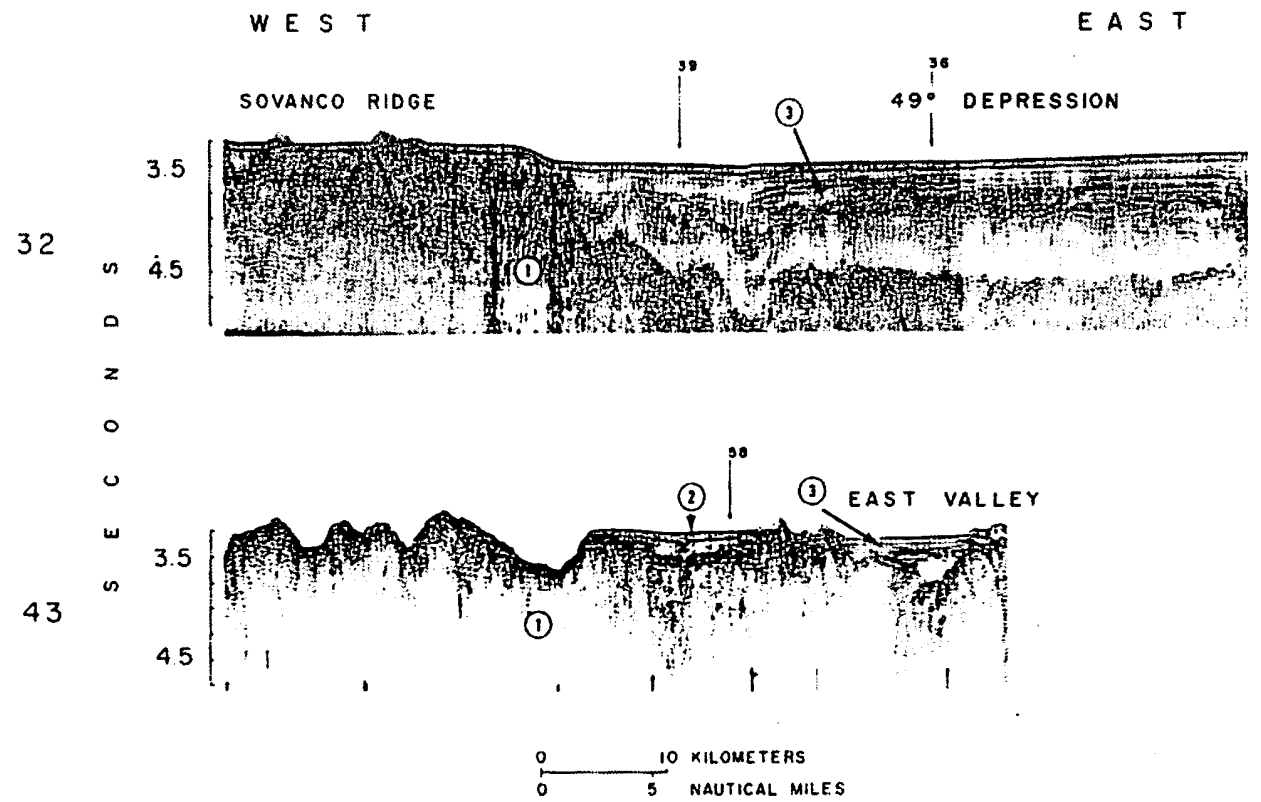

Fig.8. Seismic reflection profiles TT-53, Legs 32 and 43 . Vertical exaggeration: $\times 10.5$. Small arrows indicate crossing points of other legs. The southern extension of West Valley (above the symbol $l$ in Leg 43) is devoid of sediment. For key to numbers $1-4$, see legend of Fig.5. 
S

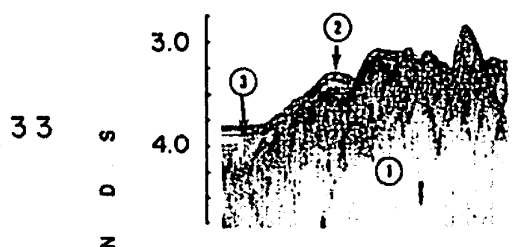

o

○

w

36

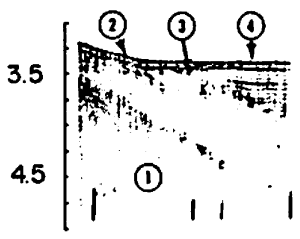

S

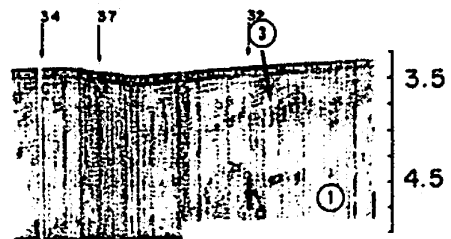

39

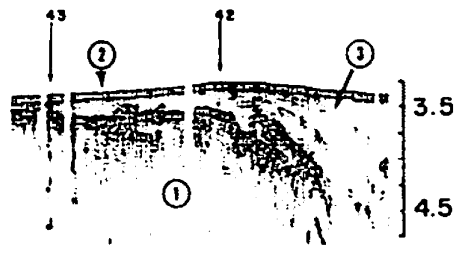

58

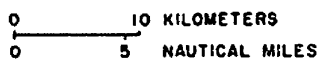

Fig.9. Seismic reflection profiles TT-53, Legs 33, 36, 39, and 58. Vertical exaggeration: $\times$ 10.5. Small arrows indicate crossing points of other legs. For key to numbers $1-4$, see legend of Fig.5.
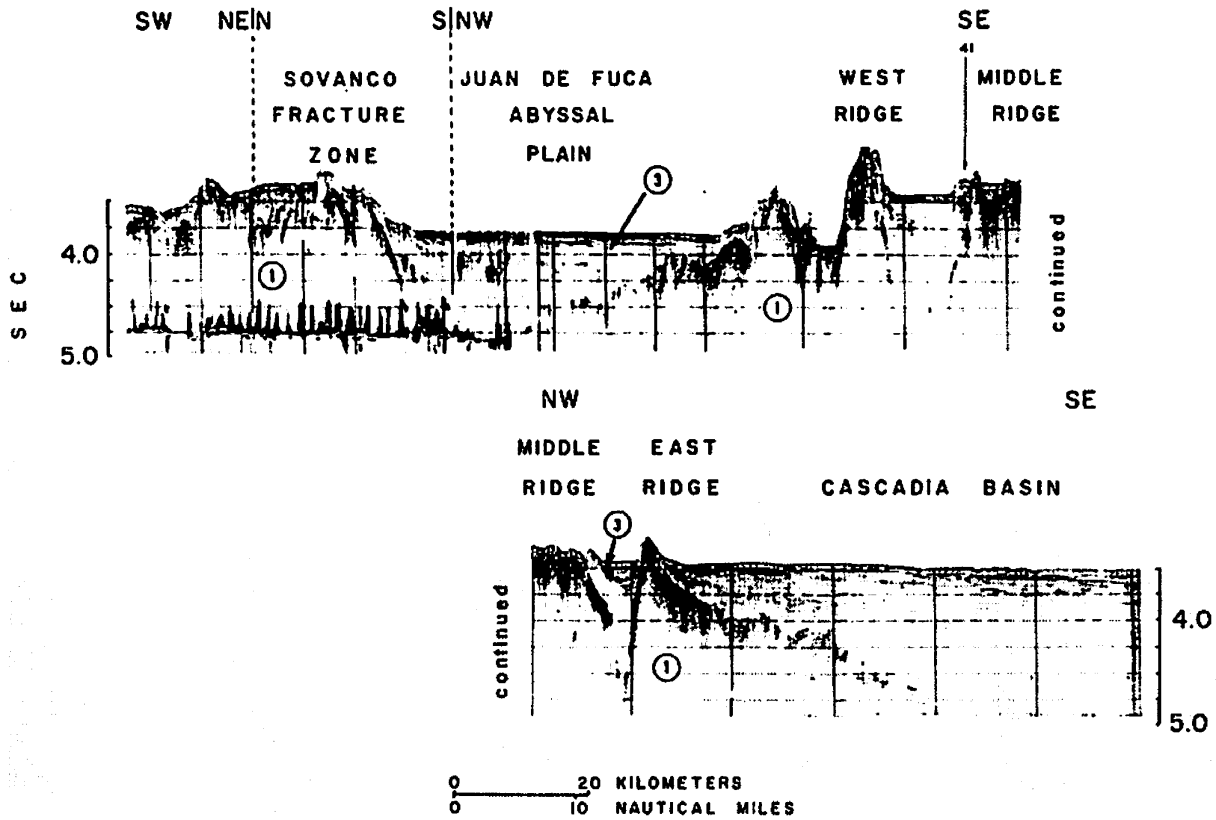

Fig.10. Seismic reflection profile of TT-48, Leg 2. Vertical exaggeration: $\times 20$. Small arrow indicates crossing point of other leg. For key to numbers $I-4$, see legend of Fig.5. 
of the Mid-Atlantic Ridge (Melson et al., 1968) and Explorer Ridge (C. R. B. Lister, personal communication, 1971) is a flat basalt surface.

\section{Lower turbidites (units $A$ and $B$ )}

The total sedimentary section averages approximately $0.5 \mathrm{sec}$ in thickness in the study area, and ranges from zero, or less than the resolution of the instruments $(0.1 \mathrm{sec})$, on seamounts and some ridges to more than $1.6 \mathrm{sec}$ in Middle Valley and more than $2 \mathrm{sec}$ near Vancouver Island. Four stratigraphic units are identifiable in the seismic profiles from the northern part of the study area. In the more structurally complex southern part, the lowest unit, unit $A$, and the youngest unit, unit $D$, are not so easily distinguished and because of this, units $A$ and $B$ are combined as the Lower Turbidites, and units $C$ and $D$ are combined as the Upper Turbidites.

Unit $A$ is a thick, rather acoustically transparent sequence forming the lowermost part of the sedimentary sequence in the $49^{\circ}$ Depression (Fig.5, Leg 31 and Fig.8, Leg 32). It appears to onlap the north side of the depression but to wedge out before cresting onto the basement high, Table Block. This interpretation is based upon the presence of faint reflectors that do not appear to be conformable with the basement except at locations where differential compaction or faulting may have taken place. Consequently, the major part of unit $A$ is assumed to be turbidites.

Unit $A$ is not present at the northern edge of the study area (Fig.5, Leg 30) where the basement is at a somewhat shallower depth. Here, unit $B$, the upper part of the Lower Turbidites, rests on the acoustic basement. Unit $B$ is characteristically composed of many thin, strong reflectors that, in the $49^{\circ}$ Depression, onlapped unit $A$ before extending northwestward over Table Block. In Fig.5 (Leg 30) unit $B$ has been upwarped by movement associated with Paul Revere Ridge. In fact, one of the unifying aspects of the Lower Turbidites that differentiates them from the Upper Turbidites, in addition to their older stratigraphic position, is their greater deformation, particularly by faulting. The seismic profiles appear to show numerous small faults.

The profiles referred to, and many of the others, show acoustically transparent sediment overlying the basement, and transparency is commonly characteristic of pelagic sediments. However, where internal reflecting horizons were recorded in this generally transparent sequence, they were found to have a depositional geometry that is more typical of turbidite-type deposition than of the basementconforming pelagic sediments. This is shown by a section across Cascadia Basin from Juan de Fuca Ridge to the continental margin off Washington (Fig.11). Practically the entire sedimentary section in this profile appears to be composed of sediment deposited by bottom-seeking currents controlled by topographic irregularities. A very minor role for pelagic sedimentation, even for reworked pelagic sediment, seems reasonable in light of the young age of the basement and the thick sequence of sediments. In the southern half of the study area the basement is less 
$W E S T$

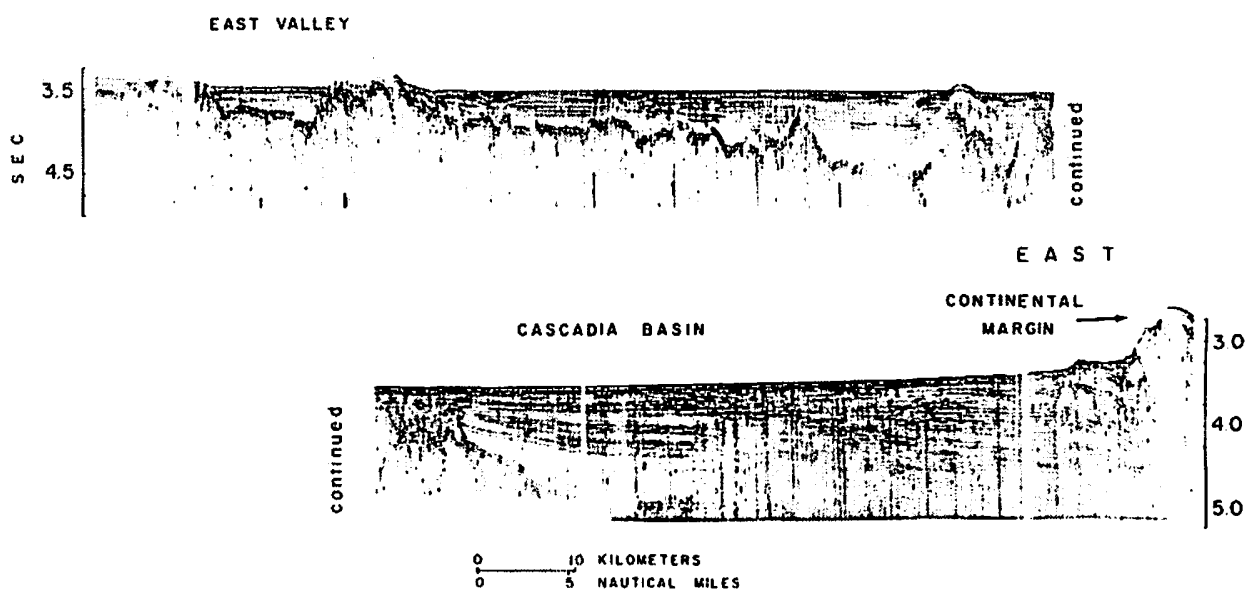

Fig.11. Seismic reflection profile of TT-53, Leg 59 from Juan de Fuca Ridge to the continental margin off Washington. Vertical exaggeration: $\times 11$.

than 2 m.y. old on the basis of the magnetic anomalies. South of the study area where the ridge crest unquestionably receives only pelagic sediment, the sediment thickness is only $2 \mathrm{~m}$ (LISTER, 1970). Thus, although some basal pelagic sediment is probably present in the study area, its exclusion from consideration is not thought materially to affect the results. Considering the transparent deposits in Fig.11 as turbidites provides a simple explanation of their distribution. On the other hand, HAYES and EwING (1971) note that they are an "enignia" when interpreted as pelagic sediments.

At the west end of the $49^{\circ}$ Depression, at least the upper part of unit $A$ appears to continue into Middle Valley and to overlie the axial magnetic anomaly, placing a maximum age of 0.7 m.y. on most of the turbidite section in the study area. As the average total thickness of sediment in the study area is about $0.5 \mathrm{sec}$, the average sedimentation rate is about $550 \mathrm{~m} / \mathrm{m} . y$. , a very rapid rate. However, other methods give similar values. For example, on the basis of ages assigned to the planktonic Foraminifera/Radiolaria ratio in cores from Cascadia Basin (DUNCAN et al., 1970), the post-Glacial section of cores in Vancouver Gap indicates a sedimentation rate of $300 \mathrm{~m} / \mathrm{m}$.y. A minimum sedimentation rate for the thick Pleistocene turbidite section in the medial valley of Gorda Ridge cored in the JOIDES Deep Sea Drilling Project is $560 \mathrm{~m} / \mathrm{m}$.y. (McManus et al., 1970, p.172). A conservative estimate of the sedimentation rate in Middle Valley is $1,700 \mathrm{~m} / \mathrm{m} . \mathrm{y}$., which seems extreme. Yet, in the Vema Fracture Zone of the Mid-Atlantic Ridge the Pleistocene turbidite sedimentation rate based on a JOIDES hole is 1,200 m/m.y. (BADER et al., 1970, p.662).

The Lower Turbidites are not present on the northeastern part of Sovanco 


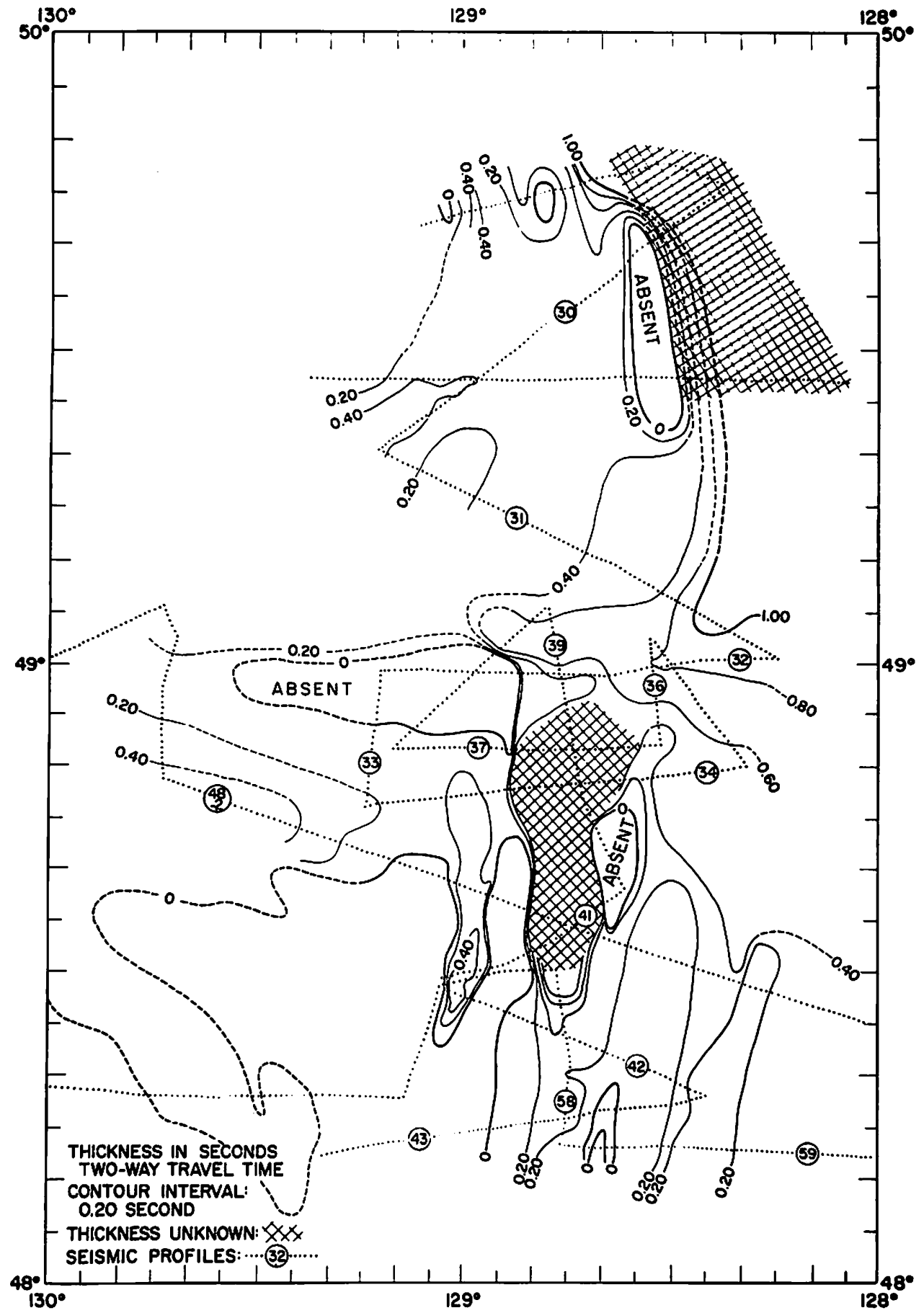

Fig.12. Isopach map of Lower Turbidites. Thickness of unit is unknown in patterned areas because of uncertainty in location of upper contact of the unit. 
Ridge (Fig.12). They are present, however, over most of the rest of the ridge, typically on fault blocks downthrown to the south (Fig.9, Leg 33; Fig.10, western part). The sediments on these fault blocks are assumed to be turbidites because of the smooth sediment surface and internal reflectors that do not conform to the basement irregularities as would be expected from pelagic sediments. In addition, the thickness of the sediment for such a young basement would necessitate an abnormally high rate of pelagic sedimentation.

South of Sovanco Ridge in the Juan de Fuca Abyssal Plain, the Lower Turbidites form only the lower part of the section, underlying $0.12-0.15 \mathrm{sec}$ of Upper Turbidites (Fig.10). The Lower Turbidites have an apparent dip to the southeast. The depth of the top of the Lower Turbidites at the southeastern terminus of the abyssal plain is approximately the same as the water depth in the adjacent West Valley. For this, and other reasons, to be noted later, the turbidites in West Valley are assumed to be Lower Turbidites.

Leg 36 (Fig.9), a profile that crosses Leg 32, shows that the Lower Turbidites have been tilted up by the elevation of Middle Ridge and that they rise from beneath the cover of the overlying Upper Turbidites. Therefore, the sedimentary section perched atop the eastern wall of Middle Valley (Fig.6, Leg 37) is the Lower Turbidites. A parallel profile across Middle Valley 3 miles farther south (Fig.6, Leg 34 ) shows the Lower Turbidites similarly perched as a vertical continuation of the basement scarp. That the east side of Middle Valley is indeed a fault is shown by Leg 39 (Fig.9) where the Lower Turbidites can be traced southward into Middle Valley but without the vertical fanning out of reflectors as seen in the Upper Turbidites. Thus, down-dropping of the basement in Middle Valley occurred after deposition of the lower sequence. The vertical displacement along the fault can therefore be measured by the relief of the basement, a relief (about $2 \mathrm{sec}$ ) that formed after Lower Turbidites time.

The turbidites atop West Ridge at its connection with Sovanco Ridge are also thought to be Lower Turbidites, a mirror image of the Middle Ridge on the opposite side of Middle Valley, which is a graben. The similarity of sediment thickness on the West Ridge-Sovanco Ridge connection (western end of Legs 34 and 37) with the Lower Turbidite thickness in West Valley and easternmost Juan de Fuca Abyssal Plain indirectly supports the identification of these sediments and the West Valley sediments as Lower Turbidites, a depositional unit formerly continuous with that forming the Juan de Fuca Abyssal Plain.

At the southern end of Middle Valley the Lower Turbidites rise to the surface (Fig.9, Leg 58) and appear to onlap the basement in the southern, shallow extension of Middle Valley. In the southern extension of Middle and East Valleys the Lower Turbidites have been slightly faulted and tilted and are present as a very thin section. Parts of the basement high between the valleys may not have been covered by these sediments. The western terminus of the Lower Turbidites on Leg 43 (Fig.8) is apparently along a fault. 


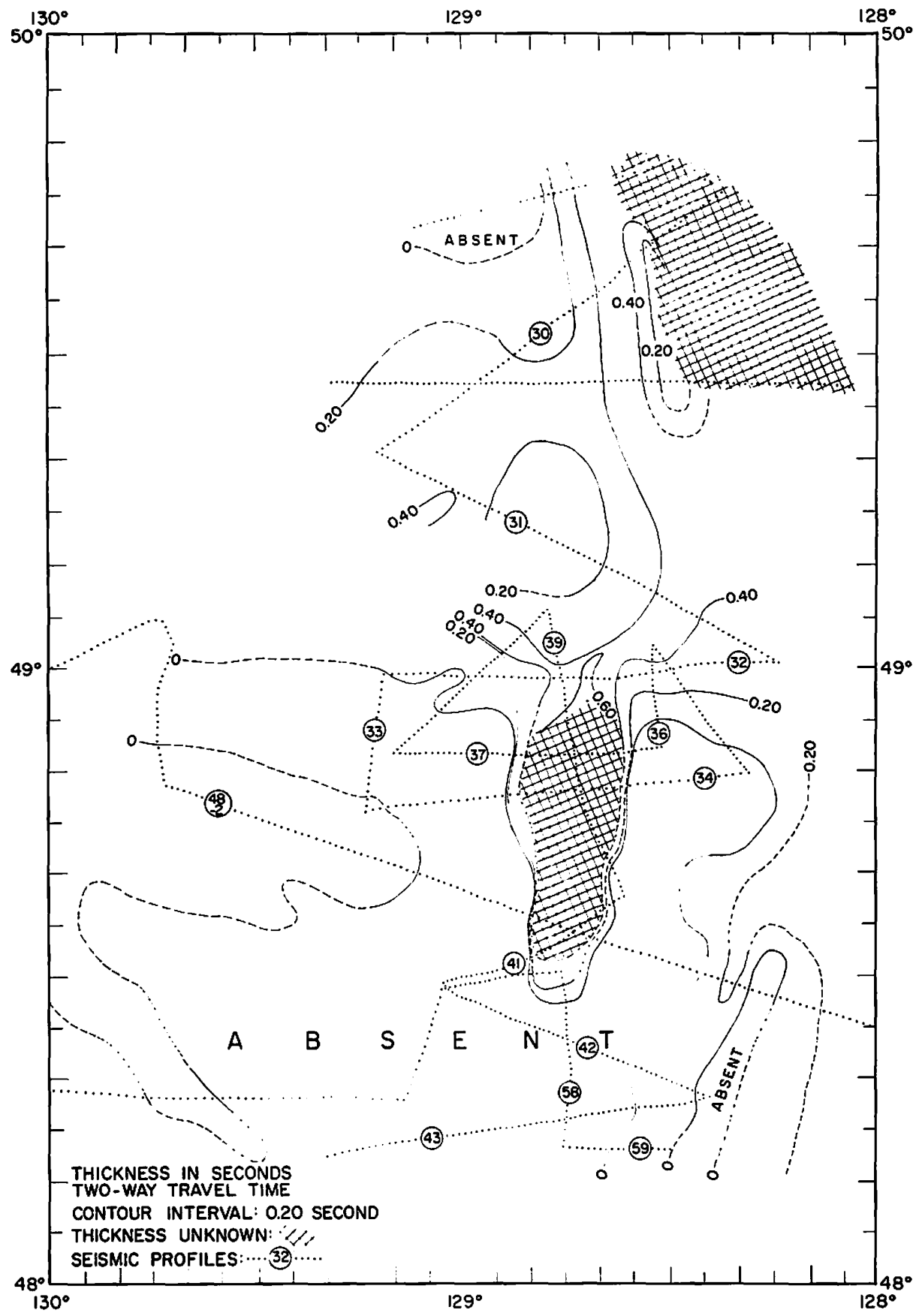

Fig.13. Isopach map of Upper Turbidites. Thickness of unit is unknown in patterned areas because of uncertainty in location of lower contact of the unit. 


\section{Upper turbidites (units $C$ and D)}

The Upper Turbidites are not only simpler structurally, being less deformed, but are simpler in their distributional pattern (Fig.13). The relationship between the Upper and Lower Turbidites is most graphically displayed in Leg 30 (Fig.5) where the Upper Turbidites onlap the upwarped Lower Turbidites. Unit $C$ forms most of the Upper Turbidite section here. Unit $D$ is associated with the more recent appearance of Revere Channel. Throughout most of the study area, however, units $C$ and $D$ cannot be separately identified and are considered together.

Against the northern end of Middle Ridge the Upper Turbidites pinch out (Fig.9, Leg 36). There is a suggestion that the older part of the generally flat-lying Upper Turbidites may have been upwarped by the ridge. In Middle Valley, on the other hand, these sediments form the main valley-fill, as shown by the vertical fanning-out of the reflectors on the north-south track into the valley (Fig.9, Leg 39). At the southern end of Middle Valley the profile (Fig.9, Leg 58) is not so distinct. Our interpretation is that the Upper Turbidites are generally flat-lying and pinch out against the upwarped Lower Turbidites, although the lower part of the unit may also be upwarped.

In the southeast part of the study area the Upper Turbidites are confined to the lowlands of East Valley and Cascadia Basin, east of East Ridge. Similar confinement to lowlands is seen in the southwest where these sediments occur only in Juan de Fuca Abyssal Plain, covering somewhat less area than Lower Turbidites.

The Upper Turbidites are not present on the ridges, and as a result do not show the deformation seen in the Lower Turbidites. The younger sediments, however, have been affected structurally in some parts of the area. They have been raised slightly on the northeast part of Sovanco Ridge and the southeast part of Table Block. Along the margins of Middle Valley, particularly in the southeast part (Fig.7, Leg 41), there has been considerable faulting of the sequence.

\section{TECTONIC HISTORY}

A record of the tectonic history of the study area begins with unit $A$. The continental source of the turbidites in unit $A$ is assumed to be essentially the same as for the younger units, as movement of the Juan de Fuca Plate (ATWATER, 1970) in the last few million years does not indicate sufficient horizontal displacement to alter the sediment source.

Unit $A$ is identifiable in the $49^{\circ}$ Depression, and presumably it is in the thick sediment section near the base of the continental margin in the northeast corner of the study area. Unit $A$, therefore, is assumed to represent the upper part of a trench-fill, with the younger sedimentary units being in part deposited farther beyond the outer margin of the trench. At the time of unit $A$ deposition, Table Block, in connection with Northeast High, was a basement high, probably receiving some pelagic sediments. Juan de Fuca Ridge south of $48^{\circ} 30^{\prime} \mathrm{N}$ was also a high, not 
receiving unit $A$ turbidites. At least the upper part of unit $A$ may be present in Middle Valley, providing a date of approximately $0.7 \mathrm{~m} . \mathrm{y}$. ago for the beginning of most of the tectonic history to be discussed.

Unit $B$ deposition began in essentially the same parts of the area covered by unit $A$, but it extended onto some of the basement highs. Table Block was covered by the unit $B$ abyssal plain which also spread over the eastern flank and onto the crest of Juan de Fuca Ridge as far as West Ridge (Fig.12). Our records do not indicate the presence of sediment on top of the southern part of West Ridge, which apparently was a basement ridge marking the edge of the abyssal plain.

The thin, strong reflectors characterizing unit $B$ can be interpreted in various ways. One possibility is that they represent coarse turbidites associated with an increase in sediment supply and energy of bottom-seeking currents. More speculatively, these conditions might represent either a glacial period in the continental source area or a tectonic effect on the continental margin associated with a general subsidence of the plate in the study area. In any event, the unit $B$ abyssal plain spread westward to Explorer Ridge and southwestward between that ridge and Juan de Fuca Ridge.

Even though the transform fault between Juan de Fuca and Explorer ridges had been in existence for some time, the Sovanco Fracture Zone had no appreciable topographic relief at the time of unit $B$ deposition, except for the northeastern end of Sovanco Ridge. This part of Sovanco Ridge protruded above the unit $B$ abyssal plain, as did Northeast High, and the seamount ranges in the southwest. The small area on Middle Ridge enclosed by the zero line on the Lower Turbidite isopach chart (Fig.12) is a consequence of the Upper Turbidite unit being in contact with the basement fault scarp and does not indicate the presence of a basement ridge at the time of deposition of unit $B$.

At the end of unit $B$ time, sometime after $0.7 \mathrm{~m} . \mathrm{y}$. ago, we presume that considerable tectonic activity took place. This assumption is based principally upon the unconformable relationship between the Upper and Lower Turbidites.

Because the initial turbidites of unit $C$ in the northern part of the study area were deposited only in the $49^{\circ}$ Depression and in a low that developed between Table Block and Northeast High, either these lows had subsided or Table Block had been uplifted, Northeast High having protruded above the turbidite deposition already in unit $B$ time. Although the relative movement is easily discernible, the absolute nature of the vertical movement is more obscure. Our conclusion is that the uplift of Table Block was the dominant movement. This conclusion is based on the relationship with Sovanco Ridge and its basis will be deferred until the ridge is discussed.

Table Block, therefore, was uplifted, producing a sag between it and Northeast High, in part a result of greater uplift along Paul Revere Ridge that caused an upwarp of the Lower Turbidite abyssal plain just south of the ridge. This uplift of Table Block was not along the same hinge line in the southeast, for the $49^{\circ}$ 
Depression now attained a slightly more northeasterly trend than in previous times.

On Juan de Fuca Ridge at the end of unit $B$ time a period of pronounced block faulting began for the grabens of Middle and West Valley and for the tilted block of East Valley. Whether the faulting in Middle Valley included the terrace fault blocks described by ATWATER and MuDIE (1968) for the medial valley of Gorda Ridge cannot be determined. Not only were the walls of the valley uplifted, however, but the block forming the valley subsided as a keystone throughout the time of deposition of the Upper Turbidites, as indicated by the vertical fanning out of the reflectors in the unit. The $49^{\circ}$ Depression, now more northeasterly in trend, formed a funnel for sediment into the cul-de-sac of Middle Valley.

The faulting along West Ridge and Sovanco Ridge placed a barrier in the direct path of the Upper Turbidites to Juan de Fuca Abyssal Plain, after the turbidites had extended onto Table Block. The faulting along West Ridge is complex because of the intersection with Sovanco Ridge. The relative movement is down to the west on West Ridge and down to the south on Sovanco Ridge. One explanation is that the west flank of Juan de Fuca Ridge subsided, along the normal faults. We prefer, however, to consider the faults as caused by uplift of West Ridge and Sovanco Ridge. This interpretation is based upon the depth of the contact between the Lower and Upper Turbidites. The contact in the eastern part of the $49^{\circ}$ Depression where both sequences are flat-lying is at about $3.8 \mathrm{sec}$, in Juan de Fuca Abyssal Plain the contact is at $3.94 \mathrm{sec}$ depth, and in West Valley, the top of the Lower Turbidites is at $3.93-3.95$ sec. These depths are so similar, even considering possible tectonic movements, that they suggest to us an approximation of the surface of the unit $B$ abyssal plain that was present as an uninterrupted surface connecting the three areas. This observation is also our basis for assuming that Table Block has been uplifted, rather than that the post-unit $B$ tectonic activity was a subsidence of the $49^{\circ}$ Depression and a sag between Table Block and Northeast High. Although the older part of the Upper Turbidites (unit $C$ ) may have reached the Juan de Fuca Abyssal Plain by a more circuitous path west of the study area where Sovanco Ridge did not form a barrier, preliminary heavy mineral evidence suggests that at least the most recent sediments on Juan de Fuca Abyssal Plain (unit $D$ ) have not been deposited in this manner. Revere Channel was apparently dammed by the uplift of Sovanco Ridge after being tilted westward away from Cascadia Basin.

Tilting of the Middle Ridge fault block occurred primarily near the fault scarp, with uplift but little tilting farther east. The northeast margin of the block is bounded by a fault that marks the limit of the Upper Turbidites.

East Ridge and East Valley are eastward-tilted fault blocks. Sufficient general uplift of the crest of Juan de Fuca Ridge occurred to restrict the Upper Turbidites to East Valley and prevent their deposition on the ridge axis at the southern edge of the study area.

In a general way the Lower Turbidites can be thought of as pre-tectonic 
sediments, and the Upper Turbidites as post-tectonic sediments. It should be noted however, that subsidence of Middle Valley took place throughout the time of Upper Turbidite accumulation and that the Upper Turbidites have been uplifted slightly at the northeast corner of Sovanco Ridge. In addition, the arching of these sediments along the southeast margin of Table Block and their pronounced faulting in Middle Valley, as well as their minor faulting in many parts of the area, indicate continued tectonic activity, but of lesser magnitude.

Even the bottom topography shows the continued affect of the tectonic activity. Hummocky and step topography, presumably caused by recent faults, are present along the southern end of Paul Revere Ridge, the northern margin of Sovanco Ridge, the hinge line at the southeast edge of Table Block, the east side of East Ridge, and the margins and center of Middle Valley. The deposits of the east levee of Revere Channel have been tilted westward by Northeast High. The seismic activity in the study area indicates that the tectonic activity is continuing today.

DISCUSSION

As inferred from the magnetic anomaly pattern of RAFF and MASON (1961), the spreading center forming the western border of the Juan de Fuca Plate (the crest of Juan de Fuca-Explorer Ridge) began changing direction from north-south to northeast-southwest approximately 7.5 m.y. ago (anomaly 4 time) (VINE, 1966; MENARD and ATwater, 1968). Explorer Ridge became segmented from Juan de Fuca Ridge at this time. The axial anomalies at both ends of Juan de Fuca Ridge may continue into the bordering transform faults, of the Blanco Fracture Zone on the south (Melson, 1969) and the Sovanco on the north (Fig.3). Correlation of any of the anomalies in the transform fault pattern with the dated sequence of anomalies from sea floor spreading is difficult. Accordingly, the ages of the transform fault magnetic anomalies are unknown, although the anomalies presumably represent "leaky" transform faults (MENARD and ATWATER, 1969) caused by the clockwise rotation of the faults.

The reorientation of the plate boundary continued until the time of anomaly 2A (about 3 m.y. ago) when the present configuration was attained for Juan de Fuca Ridge (MENARD and ATWATER, 1968). The axial anomaly of the northern part of Explorer Ridge, however, trends $040^{\circ}$, compared with the $022^{\circ}$ trend of central and southern Juan de Fuca Ridge, suggesting either a continued change in spreading direction or the effect of the adjoining North American Plate on this tiny part of the Juan de Fuca Plate. In either case, the Sovanco transform fault apparently was relocated at about the middle of Explorer Ridge, isolating the southern part possibly in a manner described in general by MENARD and ATWATER (1968).

As the crustal material recorded by the magnetic anomalies was being implaced along the axis of Juan de Fuca Ridge, the bottom topography in the study 
area apparently reflected only a broad arching similar to that of the present central and southern portions of the ridge. The pronounced basement relief of northern Juan de Fuca Ridge and the Sovanco Fracture Zone was developed subsequently. Axial valleys having as much as 2 -sec relief were formed along 25 miles $(45 \mathrm{~km})$ or so of the ridge and some were filled with turbidites. Faulting took place in rocks as young as 0.7 m.y., or less, and as old as approximately 2 m.y., at East Ridge.

A similar discrepancy between times of magnetic anomaly formation and the development of considerable topographic relief has been noted on part of the axis of the Mid-Atlantic Ridge, where the data may also be interpreted as indicating a change in spreading rate (VAN ANDEL and HEATH, 1970). An association of block faulting on the ridge axis and general uplift of the ridge crest has been related by SCHNEIDER and VOGT (1968) to increased spreading rate. On Juan de Fuca Ridge an uplift of the crest was associated with block faulting but the occurrence was so recent that no measure of a spreading-rate change is available. In any event, the northern part of Juan de Fuca Ridge has pronounced axial valleys that have not been reported from the remainder of the ridge.

The distinctive nature of the northern part of the ridge may reflect the complex plate tectonics, here. Our profiles suggest that Table Block and Sovanco Ridge were recently uplifted and that compressive folds and faults are present along the Vancouver Island continental margin. The bottom topography between Sovanco Ridge and Vancouver Island provides numerous indications of recent tectonic movement. The earthquake epicenters are not along the margins of this northern, salient-like block of the Juan de Fuca Plate; they are dispersed throughout the block (Fig.3). In addition, the magnetic anomaly pattern is partly distorted. These observations suggest that this block of the Juan de Fuca Plate, between Juan de Fuca and Explorer ridges, is under stress and is undergoing internal deformation. Internal deformation has previously occurred in the Juan de Fuca Plate, and even the Pacific Plate, on the basis of the discontinuities in the magnetic anomalies (RAFF and Mason, 1961; Vine, 1966; Peter and Lattimore, 1969). At present it is occurring in the southernmost part of the Juan de Fuca Plate, near the Mendocino Fracture Zone (ATWATER, 1970).

According to the calculations of ATwATER (1970), the movement of the Juan de Fuca Plate relative to the North American Plate is approximately 2.5 $\mathrm{cm} /$ year toward the northeast. This rate may not apply to the northern block of the Juan de Fuca Plate, however, because of the presumed internal deformation. Consequently the movement of this northern block relative to the North American Plate is unknown; except that the deformation along the continental slope suggests that there is compression between them. If the northward movement of this block relative to the North American Plate is less than the northward movement of the Pacific Plate relative to the North American Plate, then this salient-like part of the Juan de Fuca Plate would be compressed between the two larger plates. Considering the location, with possible compression on two sides of the block and a movement 
of the block that is approaching parallelism with the spreading center of the Explorer Ridge crest; together with the very small size of the block, it seems possible that the position of this salient of the Juan de Fuca Plate may be untenable and that the seismic activity throughout this salient is the beginning of its separation from the rest of the Juan de Fuca Plate. The block may be rotating into severance, or Juan de Fuca Ridge and the Queen Charlotte fault may extend to sever it in a manner similar to that proposed by MENARD and ATWATER (1969) for a block between the Murray and Molokai fracture zones.

\section{CONCLUSIONS}

Modification of basement relief of a ridge axis and a fracture zone can occur sometime after the implacement of crustal material producing the magnetic anomalies. This relief may be formed in a relatively short period of time, on the order of a few hundred thousand years at most, and the vertical movements producing the relief are not confined to the axial anomaly part of the ridge but can occur on other parts of the ridge crest, as well as on fracture zones. Whatever may be the constraints on formation of block-faulted axial valleys, they can be formed over local stretches of a ridge otherwise characterized by a poorly-defined medial valley. These complex tectonics are probably associated with complexities in the motions of the lithospheric plates. Part of the basement relief at the northern end of Juan de Fuca Ridge may have resulted from aberrations in the movement of the adjoining Juan de Fuca Plate. Seismic profiles, in conjunction with bathymetry, earthquake-epicenter locations, and magnetic anomaly patterns suggest that the northern part of the Juan de Fuca Plate is not rigid and is undergoing internal deformation.

\section{ACKNOWLEDGEMENTS}

This work was supported by contract N-00014-67-A-0103-0014 with the Office of Naval Research. This is Department of Oceanography, University of Washington, Contribution No. 615. We wish to thank C. R. B. Lister, R. T. Merrill, D. W. Scholl and E. A. Silver for their helpful comments.

\section{REFERENCES}

ATwater, T. M., 1970. Implications of plate tectonics for the Cenozoic tectonic evolution of western North America. Geol. Soc. Am. Bull., 81: 3513-3536.

Atwater, T. M. and Mudie, J. D., 1968. Block faulting on the Gorda Rise. Science, 159: 729-731.

BAder, R. G. et al., (Multi-author volume), 1970. Initial Reports of the Deep Sea Drilling Project. U.S. Government Printing Office, Washington, D.C., 4: 753 pp.

Chase, R. L., BarR, S. and Thomlinson, A. G., 1970. Deformation revealed by csp on margins of the northern sector of Juan de Fuca lithospheric plate, northeast Pacific Ocean (abstr.). Geol. Soc. Am. Program, 1970 Ann. Meet., 2: 518.

CоUCH, R. W., 1969. Gravity and structure of the Scott Islands Fracture Zone (abstr.). EOS, Trans. Am. Geophys. Union, 50: 633. 
Dehlinger, P., Couch, R. W., McManus, D. A. and Gemperle, M., 1971. Oceanic structure northern California to British Columbia. In: A. E. MAxwell (Editor), The Sea. Interscience, New York, N.Y., 4: 133-189.

Duncan, J. R., Fowler, G. A. and Kulm, L. D., 1970. Planktonic foraminiferan-radiolarian ratios and Holocene-Late Pleistocene deep-sea stratigraphy off Oregon. Geol. Soc. Am. Bull., 81: 561-566.

Ewing, J., Ewing, M., Aitken, T. and Ludwig, W. J., 1968. North Pacific sediment layers measured by seismic profiling. In: L. KNOPOFF, C. L. Drake and J. H. Pembroke (Editors), The Crust and Upper Mantle of the Pacific Area. Geophys. Monogr. Am. Geophys. Union, Washington, D.C., 12: 147-173.

Hamilton, E. L. and Menard, H. W., 1968. Undistorted turbidites on the Juan de Fuca Ridge (abstr). Trans. Am. Geophys. Union, 49: 208.

Hayes, D. E. and Ewing, M., 1971. Pacific boundary structure. In: A. E. Maxwell (Editor), The Sea. Interscience, New York, N.Y., 4: 29-72.

Heirtzler, J. R., Dickson, G. O., Herron, E. M., Pitman III, W. C. and le Pichon, X., 1968. Marine magnetic anomalies, geomagnetic field reversals, and motions of the ocean floor and continents. J. Geophys. Res., 73: 2119-2136.

Langseth JR., M. G., Le Pichon, X. and Ewing, M., 1966. Crustal structure of the mid-ocean ridges, 5. Heat flow through the Atlantic Ocean floor and convection currents. J. Geophys. Res., 71: 5321-5355.

Lister, C. R. B., 1970. Heat flow west of the Juan de Fuca Ridge. J. Geophys. Res., 75: 2648-2654.

MCKenzie, D. P. and SClater J. G., 1969. Heat flow in the eastern Pacific and sea floor spreading. Bull. Volcanol., 31: 101-117.

McManus, D. A., 1967. Physiography of Cobb and Gorda Rises, northeast Pacific Ocean. Geol. Soc. Am. Bull., 78: 527-546.

McManus, D. A., 1970. Comparison of three methods of measuring or estimating sonic velocity in sediments. In: D. A. McManus et al. (multi-author volume) Initial Reports of the Deep Sea Drilling Project, U.S. Government Printing Office, Washington, D.C., 4: 545-549.

McManus, D. A. et al. (multi-author volume), 1970. Initial Reports of the Deep Sea Drilling Project. U.S. Government Printing Office, Washington, D.C., 5: 827 pp.

MeLson, W. G., 1969. Preliminary results of a geophysical study of portions of the Juan de Fuca Ridge and Blanco Fracture Zone. Environ. Sci. Serv. Adm. Tech. Memo. C and GSTM, 6: $33 \mathrm{pp}$.

Melson, W. G., Thompson, G. and Van Andel, TJ. H., 1968. Volcanism and metamorphism in the Mid-Atlantic Ridge, $22^{\circ}$ North Latitude. J. Geophys. Res., 73: 5925-5941.

Menard, H. W. and Atwater, T., 1968. Changes in direction of sea-floor spreading. Nature, 219: 463-467.

Menard, H. W. and Atwater, T., 1969. Origin of fracture zone topography, Nature, 222: 1037-1040.

Menard, H. W. and Mammerickx, J., 1967. Abyssal hills, magnetic anomalies, and the East Pacific Rise. Earth Planet. Sci. Lett., 2: 465-472.

Pavoni, N., 1966. Tectonic interpretation of the magnetic anomalies southwest of Vancouver Island. Pure Appl. Geophys., 63: 172-177.

Peter, G. and Lattimore, R., 1969. Magnetic structure of the Juan de Fuca-Gorda Ridge area. J. Geophys. Res., 74: 586-593.

RAFF, A. D. and MASON, R. G., 1961. Magnetic survey off the west coast of North America, $40^{\circ} \mathrm{N}$. Latitude to $52^{\circ} \mathrm{N}$. Latitude. Geol. Soc. Am. Bull., 72: 1267-1270.

SChNeIDER, E. D. and Vogt, P. R., 1968. Discontinuities in the history of sea-floor spreading. Nature, 217: 1212-1222.

Shor Jr., G. G., Dehlinger, P., Kirk, H. K. and French, W. S., 1968. Seismic refraction studies off Oregon and northern California. J. Geophys. Res., 73: 2175-2194.

TobiN, D. G. and Sykes, L. R., 1968. Seismicity and tectonics of the northeast Pacific Ocean. J. Geophys. Res., 73: 3821-3845.

Van Andel, TJ. H. and Heath, G. R., 1970. Tectonics of the Mid-Atlantic Ridge, $6-8^{\circ}$ South Latitude. Mar. Geophys. Res., 1: 5-36.

VINE, F. J., 1966. Spreading of the ocean floor: new evidence. Science, 154: 1405-1415. 


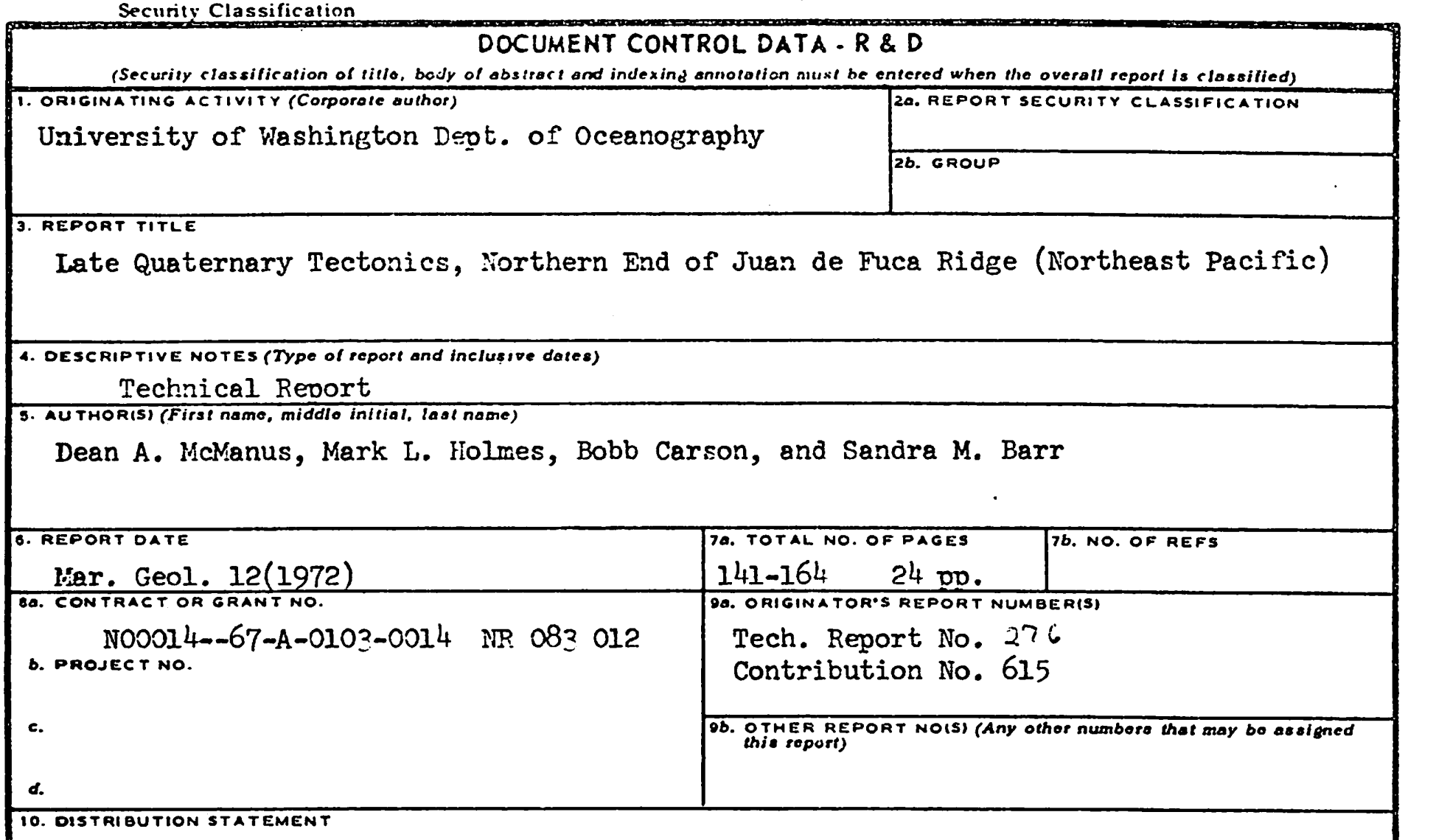

For public release; distribution unlimited.

11. SUPPLEMENTARY NOTES
$\cdot$

13. ADstaAct Seismic reflection profiles from the northern end of Juan de Fuca Ridge reveal three axial valleys having a basement relief of as much as 2 sec (two-way travel) time). A thick sequence, presumably of turbidites, mainly less than $0.7 \mathrm{~m} . \mathrm{y}$. old, covers much of the area. The oldest turbidites form the upper part of the fill of a possible Tertiary trench between the ridge and North America. The second turbidite unit extends beyond the trench and once formed an abyssal plain over most of northern Juan de Fuca Ridge and the area west to Explorer Ridge. Following formation of the plain, vertical movements began trat broadly uplifted the crest of Juan de Fuca Ridge, block-faulted its northern end, produced faulting along Sovanco Fracture Zone, and upwarped the basement north of the ridge. Younger turbidites have filled the lowlands created by the vertical movemenis. The present sea floor topography and seismic activity show evidence of continued movements.

Our findings indicate that the basement relief of the ridge crest and fracture zone were formed after the time of creation of the magnetic anomalies associated with sea floor spreading. Although abruptly initiated, these vertical movements have continued in a moderated form to the present. The vertical movements are thought to be associated with horizontal plate motions in this complex area and with the episodic release of strain as the northwest-salient block of the Juan de Fuca Plate is possibly being severed from the remainder of the plate. 